Gut, 1969, 10, 804-811

\title{
The Paneth cell in disease
}

\author{
KLAUS LEWIN ${ }^{2}$ \\ From the Department of Pathology, Vincent Square Laboratories of Westminster Hospital, London
}

\begin{abstract}
SUMMARY A systematic study of the distribution of Paneth cells in disease of the small and large intestine is described. In disease of the small intestine and appendix there is usually a fall in the number of Paneth cells normally present. Occasionally, as in Crohn's disease, there may be proliferation. In disease of the colon the number of Paneth cells is unaltered in functional and developmental disorders and increased in the inflammatory and neoplastic diseases. lt is suggested that the Paneth cell proliferation originates from stem cells in the colon.

The significance of an increase in Paneth cells is discussed and it is suggested that in ulcerative colitis it may produce a self-perpetuating and destructive state.
\end{abstract}

Paneth cells were discovered by Schwalbe in 1872 and later described more fully by Paneth in 1888 . They are found in the intestinal mucosa of a wide variety of animals in the fundus of the crypts of Lieberkühn, and are characterized by large granules visible in both the fresh and fixed state in the apical supranuclear part of the cell. In man they are found normally in the small intestine and appendix, and have been reported in the colon (Hamperl, 1928; Verity, Mellinkoff, Frankland, and Greipel, 1962), the stomach, and the pancreas (Helly, 1905). Their presence in the last three sites has not been generally confirmed.

In diseases of the intestinal tract the number of Paneth cells normally present may be altered. In the stomach there is proliferation in association with gastritis and gastric carcinoma. In the small intestine the number is diminished in coeliac disease (Creamer and Pink, 1967). In the colon Paneth cells are found in increased numbers in ulcerative colitis (Watson and Roy, 1960; Paterson and Watson, 1961), in 'tuberculous typhlitis' (Hertzog, 1937), in benign tumours (Thorel, 1898; Schmidt, 1905; Lendrum, 1948; Morson, 1955; Gibbs, 1967; and in others), and in carcinoma (Schmidt, 1905; Kerr and Lendrum, 1936; Laurén, 1961 ; Gibbs, 1967).

The purpose of this paper is to report the findings of a systematic study of the effect of intestinal disease on the Paneth cell, because most of our

${ }^{1}$ The subject matter has formed part of a thesis for the MD degree of the University of London, 1966.

'Present address: Department of Pathology, Stanford University Hospital, Stanford, California 94305, USA. present knowledge is restricted to isolated reports in connexion with other investigations of the intestine.

\section{MATERIAL AND METHODS}

The diseases which were studied are listed in Table I. The material consisted of biopsy and resection specimens obtained predominantly at operation and occasionally at necropsy. Wherever possible, the lesion, mucosa adjacent to the lesion, and normal mucosa were examined. In the specimens involving long segments of bowel, blocks were selected at frequent intervals along their length. In every case the diagnosis was made on histological and not on clinical grounds.

All specimens were fixed in $10 \%$ formol saline for 24 to 48 hours. Representative blocks were embedded in paraffin wax and sectioned in the normal fashion and then stained in the standard way with Mayer's haematoxylin and eosin. Special stains which were used included Lendrum's phloxine tartrazine, Masson's trichrome, and a combined ammoniacal silver and trichrome stain.

With haematoxylin and eosin there was poor contrast between the granules, the nucleus, and the surrounding stroma. The best contrast was obtained with Masson's trichrome stain and Lendrum's phloxine tartrazine method. In the former, the Paneth cell granules retained their red colour from the dyes Ponceau $2 \mathrm{R}$ and acid fuchsin after differentiation with phosphomolybdic acid. The nuclei were stained blue-black by the haematoxylin and the surrounding stroma took up the counterstain, light green. In Lendrum's phloxine tartrazine method, the Paneth cell granules remained red after differentiation with tartrazine in cellusolve, but the cytoplasm and collagen turned a pale yellow. The nuclei were stained blue black by the haematoxylin. Differentiation was much easier to control in the trichrome method and 
TABLE I

MATERIAL STUDIED

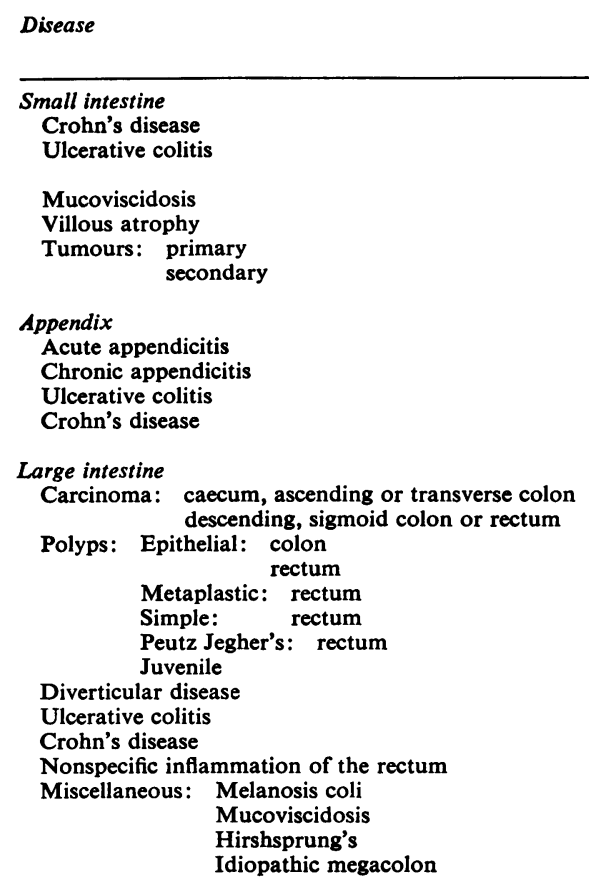

more consistent results were obtained. For this reason the trichrome method was found to be the most reliable in demonstrating Paneth cells.

With the last two stains, the morphology of the Paneth cell was quite distinct from that of the other glandularcells of the intestinal tract, although the argentaffin cell granules stained in a similar manner to the Paneth cell granules. This occasionally caused confusion in obliquely cut sections, in which the relationship of the position of the granules to the nucleus was difficult to assess. (The Paneth cell granules were supranuclear and the argentaffin cell granules were infranuclear.) Where confusion as to the nature of the granule occurred, a combined ammoniacal-silver-trichrome stain was helpful since the argentaffin cell granules took up the silver stain and appeared black, whereas the Paneth cell granules were unaffected and took up the Ponceau 2R and fuchsin stains.

ESTIMATION OF NUMBER OF PANETH CELLS The number of Paneth cells in each section was estimated by obtaining a Paneth cell count. This was calculated by dividing the number of crypts of Lieberkühn which contained Paneth cells by the total number of crypts of Lieberkühn in that section. The ratio was then expressed as a percentage. For the large intestine an average figure from those lesions with Paneth cells was calculated for each of the special groups. Although the Paneth cell count was usually related to the total number of Paneth cells per section it was really only an estimate of the number of crypts of Lieberkühn containing Paneth cells. It was there-
Specimen No. of Specimens Examined

$\begin{array}{lr}\text { Resection } & 9 \\ \text { Resection of terminal ileum with } & \\ \text { large bowel } & 17 \\ \text { Resection and necropsy } & 4 \\ \text { Peroral biopsy } & 18 \\ \text { Resection } & 6 \\ \text { Resection } & 6 \\ & \\ \text { Resection } & \\ \text { Resection } & 30 \\ \text { Removal with colon } & 35 \\ \text { Removal with colon } & 29 \\ & 3 \\ \text { Right hemicolectomy } & \\ \text { Abdomino-perineal resection } & \\ \text { Resection } & 35 \\ \text { Local excision } & 29 \\ \text { Local excision } & 15 \\ \text { Local excision } & 23 \\ \text { Local excision } & 16 \\ \text { Local excision } & 3 \\ \text { Local resection } & 1 \\ \text { Total colectomy } & 4 \\ \text { Resection } & 53 \\ \text { Biopsy } & 44 \\ \text { Resection } & 22 \\ \text { Necropsy } & 26 \\ \text { Resection } & 3 \\ \text { Resection } & 3 \\ & 1 \\ & 1\end{array}$

fore necessary sometimes to add a rider about the number of cells per crypt. This was expressed as decreased, normal, or increased.

\section{OBSERVATIONS}

In order to evaluate the influence of disease on the Paneth cell, a preliminary investigation, details of which are published elsewhere (Lewin, 1969), was undertaken to determine the distribution of the Paneth cell in health. In the small intestine they were found in the jejunum and ileum in equal numbers and they occurred in almost every crypt of Lieberkühn. In the appendix they were found in about $75 \%$ of specimens, but unlike the frequency in the small intestine they occurred only in about $8 \%$ of the crypts and the number per crypt was small. In the large intestine, Paneth cells were very sparse and were only found in $26 \%$ of specimens. They occurred mainly in the caecum and ascending colon and rarely more distally although they could occasionally be found as far as the rectum.

The morphology of the Paneth cell is highly characteristic: it is a cone-shaped cell with its base adjacent to the basement membrane and apex bordering the lumen of the crypts of Lieberkühn. Its nucleus lies at the base of the cell. The cytoplasm contains large granules situated in the upper half 


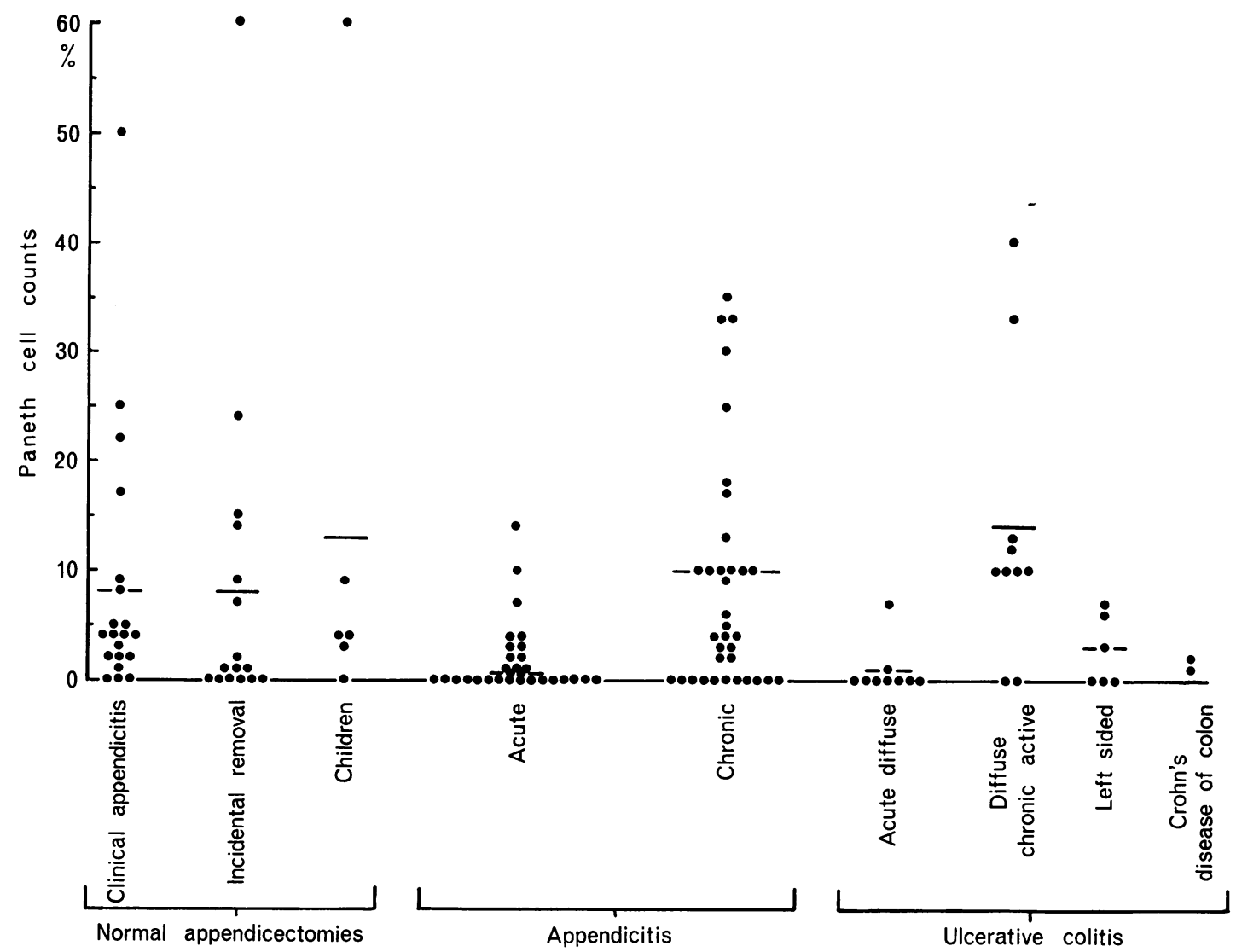

FIG. 1. Paneth cell counts in the normal and diseased appendix.

of the cell and variable in number. They take up numerous dyes, such as eosin, safranine, acid fuchsin, azan stains, phosphotungstic acid haematoxylin, and aniline dyes. In disease the general morphology of the cell remains unaltered. The degree of granularity, however, may vary but the changes are not consistent.

The influence of disease of the small intestine and appendix on the Paneth cell is summarized in Table II and Figure 1. In general, diseases of the small intestine caused a fall in number of Paneth

TABLE II

INFLUENCE OF DISEASE OF THE SMALL INTESTINE ON THE PANETH CELL

\begin{tabular}{ll} 
Disease & $\begin{array}{l}\text { Effect on } \\
\text { No. of Paneth Cells }\end{array}$ \\
\hline Crohn's disease & $\begin{array}{l}\text { Usually decreased } \\
\text { Sometimes increased }\end{array}$ \\
Ulcerative colitis with reflux ileitis & $\begin{array}{l}\text { Decreased } \\
\text { Decreased } \\
\text { Mucoviscidosis }\end{array}$ \\
Villous atrophy & $\begin{array}{l}\text { Decreased } \\
\text { Tumours }\end{array}$ \\
Decreased
\end{tabular}

cells normally present. There was one exception, namely, some cases of Crohn's disease in which there was an increased number of Paneth cells (Fig. 2).

In Crohn's disease the decrease in number of Paneth cells occurred in the severely diseased segments. In the less acutely inflamed specimens and in areas where there was evidence of repair, proliferation of Paneth cells was seen. The Paneth cells were often seen high up on the sides of the gland crypts and occasionally even on the intestinal villi (Fig. 3). These changes occurred only in diseased segments.

In villous atrophy there was a diminution in number of Paneth cells in biopsies with shortened or absent villi, but no change was seen in biopsies with spade villi (Fig. 4). In mucoviscidosis there was also a marked reduction in the number of Paneth cells and where these were present they contained fewer, poorly staining granules. Also in some areas Paneth cell depletion appeared to be associated with cystically dilated gland crypts filled with abnormal mucus. In ulcerative colitis 


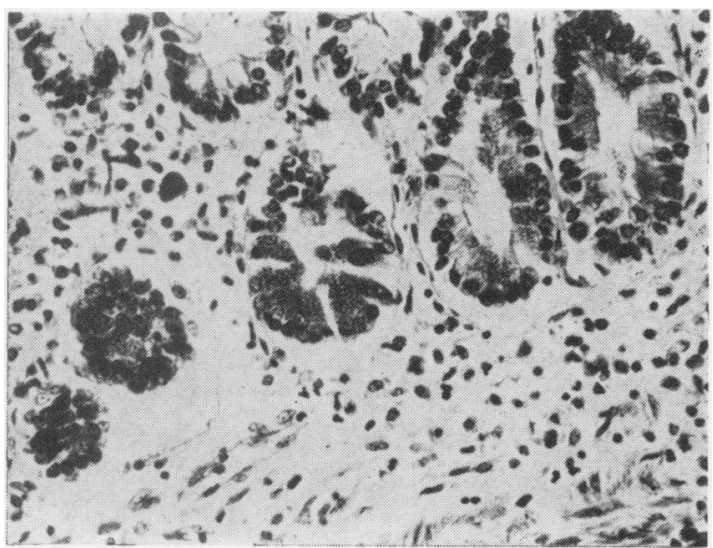

FIG. 2.

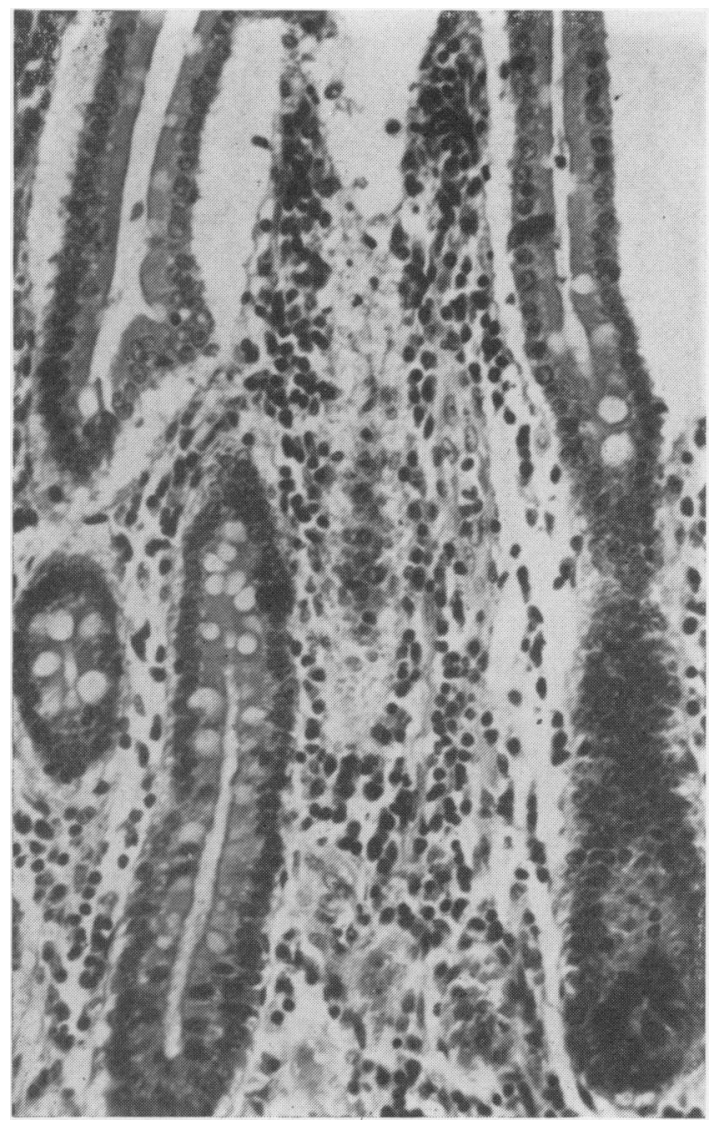

FIG. 3.

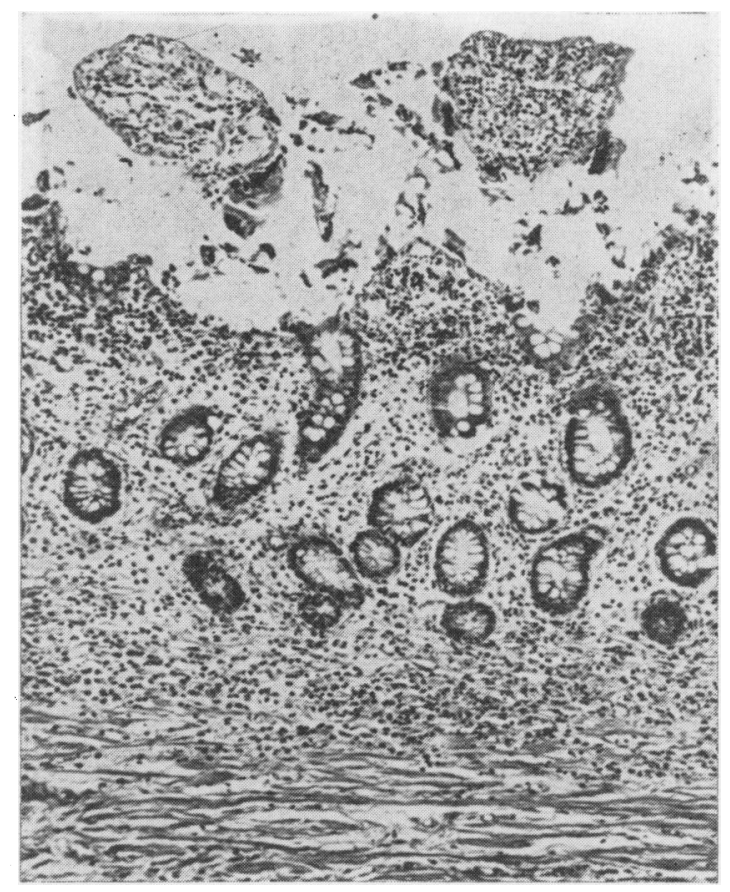

FIG. 4.

FIG. 2. Ileum in Crohn's disease. Section shows marked proliferation of Paneth cells. Trichrome $\times 160$.

FIG. 3. Ileum in Crohn's disease showing proliferation of Paneth cells up the sides of the crypts of Lieberkühn. One Paneth cell is also seen at the base of a villus in the upper right half of the photomicrograph. Trichrome $\times 160$.

FIG. 4. Peroral jejunal biopsy showing villous atrophy. Note the absence of Paneth cells at the crypts of Lieberkühn. Trichrome $\times 80$. 
TABLE III

DISTRIBUTION OF PANETH CELLS IN DISEASE OF THE LARGE INTESTINE

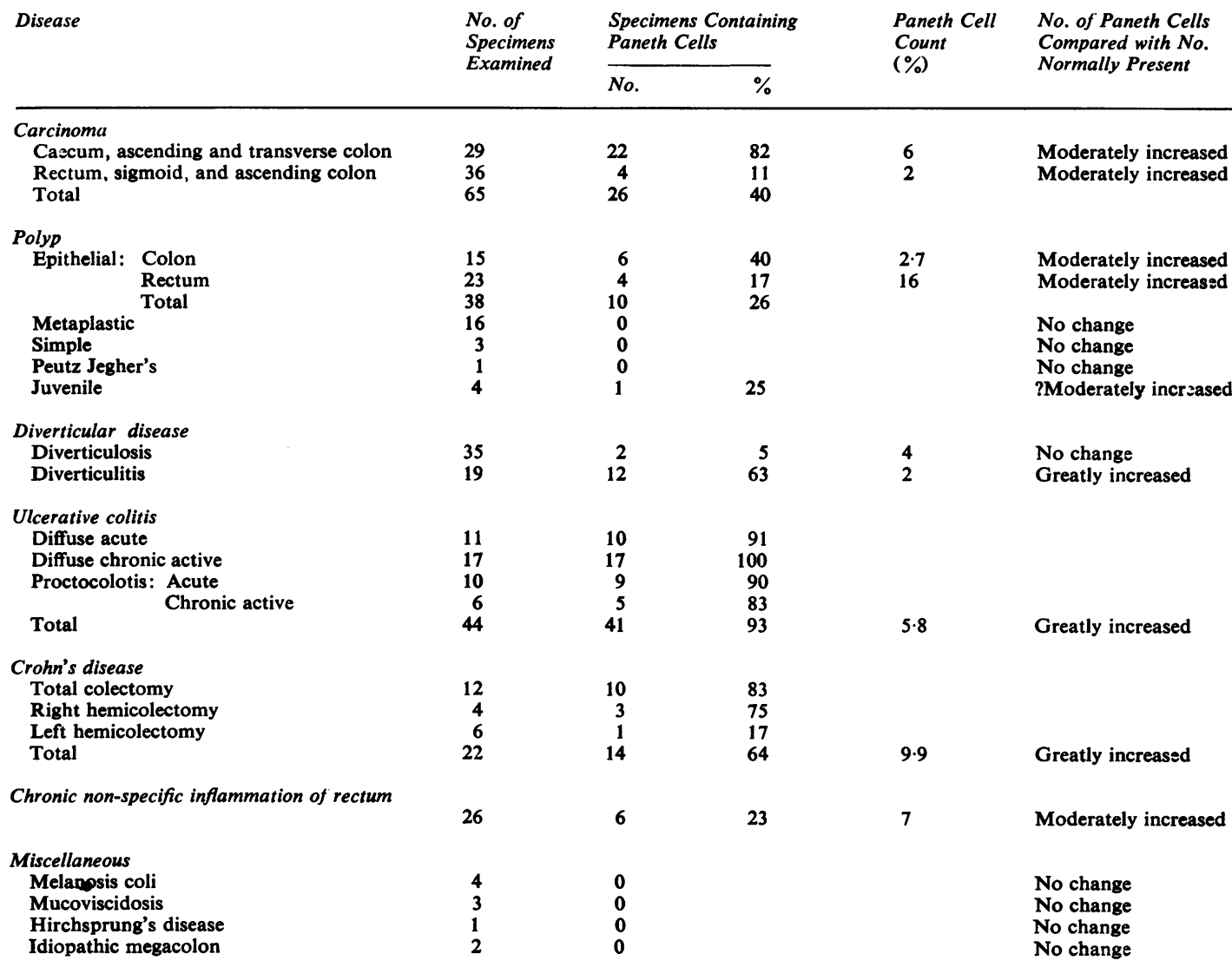

with reflux ileitis and tumours the number of Paneth cells was reduced in the diseased segments only. In the case of tumours, there was no difference in behaviour between primary and secondary lesions.

All the diseases of the appendix, with the exception of appendicitis and some cases of ulcerative colitis, showed a decrease in number of Paneth cells. In some cases the reduction was due to mucosal ulceration, but in the majority this was not the only factor, because in the nonulcerated portions of the mucosa, the number of Paneth cells was also reduced. In chronic appendicitis the number of Paneth cells was unchanged. In ulcerative colitis, those appendices associated with the diffuse chronic form showed proliferation of Paneth cells.

The influence of disease of the colon on the Paneth cell is summarized in Table III and the conditions associated with an increased number of Paneth cells are described briefly below.

In carcinoma there was a moderate increase in the number of Paneth cells. These were found in the mucosa immediately adjacent to the tumour and occupied their usual position in the crypts of Lieberkühn. They were found more frequently in carcinoma of the caecum, ascending, and transverse colon than in carcinoma of the descending colon, sigmoid colon, and rectum. In adenomas there was a moderate increase in the number of Paneth cells, but in contrast to carcinoma, they were found both within the polyps and in the adjacent mucosa. The Paneth cells occurred at the bases of the glands and were found twice as commonly in the colon as in the rectum. In the colon all the tumours were simple adenomas but in the rectum three were villous papillomas. One villous papilloma consisted mainly of Paneth cells, thus giving an abnormally high average Paneth cell count for the rectal epithelial polyps (Table III).

In diverticular disease Paneth cells were very uncommon in uninflamed specimens and abundant in inflamed ones. In the latter they occurred more commonly in healed or chronically inflamed 


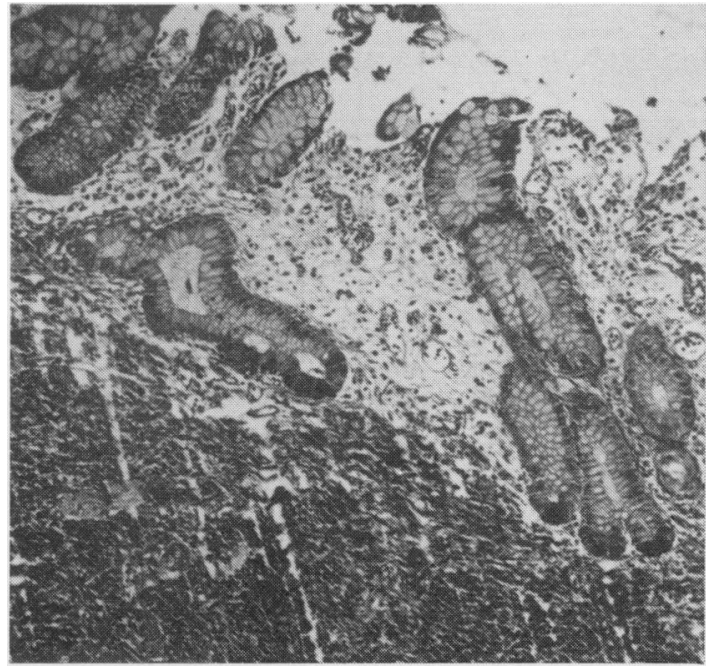

FIG. 5. Colon in chronic active ulcerative colitis. Note the numerous Paneth cells within the distorted glands. Trichrome $\times 100$.

diverticula than in acutely inflamed ones. In ulcerative colitis Paneth cells occurred in very large numbers in almost all specimens (Fig. 5). The distribution of Paneth cells varied according to the severity and extent of the lesion (Table IV). In diffuse ulcerative colitis, in which the whole colon was diseased, Paneth cells were most abundant in the caecum and showed a gradual falling off in number from caecum to rectum. The Paneth cells were found more frequently in the chronic active phase of the disease than in the acute phase. These differences in Paneth cell distribution were not apparent in specimens with distal proctocolitis although Paneth cells were frequently seen in the histologically normal sections from the caecum, ascending colon, and transverse colon. Four specimens of ulcerative colitis with ileorectal anastomoses were also examined. They were all diseased and the

TABLE IV

AVERAGE PANETH CELL COUNTS OF LARGE INTESTINE IN ULCERATIVE COLITIS

Severity of Disease Paneth Cell Counts

\begin{tabular}{|c|c|c|c|c|}
\hline Caecum & $\begin{array}{l}\text { Ascend- } \\
\text { ing } \\
\text { Colon }\end{array}$ & $\begin{array}{l}\text { Trans- } \\
\text { verse } \\
\text { Colon }\end{array}$ & $\begin{array}{l}\text { Des- } \\
\text { cending } \\
\text { Colon }\end{array}$ & Rectum \\
\hline
\end{tabular}

\begin{tabular}{lllllll}
\hline $\begin{array}{c}\text { Diffuse acute } \\
\text { ulcerative colitis }\end{array}$ & 12 & 6 & 3 & 2 & 2 & 10 \\
$\begin{array}{c}\text { Diffuse chronic active } \\
\text { ulcerative colitis }\end{array}$ & 11 & 12 & 9 & 8 & 4 & \\
$\begin{array}{c}\text { Distal acute ulcerative } \\
\text { colitis }\end{array}$ & 6.5 & 10 & 4.4 & 16 & 5 & \\
$\begin{array}{c}\text { Distal chronic active } \\
\text { ulcerative colitis }\end{array}$ & 10 & 10 & 8.7 & 16 & 11 \\
$3 *$ & & & & &
\end{tabular}

exact line of demarcation between ileum and rectum was difficult to locate because ileal villi were blunted, so giving the ileal mucosa a colonic appearance. In none of these specimens was there any evidence of Paneth cell migration from the small intestine into the colon.

Paneth cells were found in large numbers in Crohn's disease of the colon and the pattern of Paneth cell distribution in the diffuse disease was similar to that in diffuse chronic active ulcerative colitis.

\section{DISCUSSION}

Patzelt (1936) and Morson (1959) stated that the Paneth cells in the small intestine were unaffected in disease, but did not mention which diseases were examined. However, the results of this study have shown that in disease there is a change in the number of Paneth cells normally present. Thus there was a reduction in the number of Paneth cells in Crohn's disease, ulcerative colitis with reflux ileitis, primary and secondary tumours, mucoviscidosis, and severe villous atrophy, and an increase in number in certain cases of Crohn's disease. The factors responsible for the variation in number of the Paneth cells did not appear to be the same in every disorder.

In Crohn's disease, ulcerative colitis with reflux ileitis, and tumours the reduction appeared to be the result of nonspecific injury due to the disease process. This was because the reduction occurred only in those areas showing disease involving the crypts of Lieberkühn and not in the adjacent healthy segments. In some cases the reduction in Paneth cells was actually due to mucosal ulceration. In mucoviscidosis the most important abnormality seemed to be an inadequate or abnormal synthesis of granules, because many of the cells contained few or poorly formed granules. This would not be surprising since specialized cells other than the goblet cells, for example those in sweat glands, are also abnormal in this disease. Pressure atrophy of Paneth cells by cystically dilated crypts of Lieberkühn filled with abnormal mucus contributed to a minor extent to a reduction in Paneth cells. In villous atrophy the small intestine takes on the appearance of colonic mucosa and there is a great diminution in the number of Paneth cells. Creamer and Pink (1967) attributed the mucosal flattening to the absence of Paneth cells, which they believed played a role in the nutrition of the mucosa. However, Paneth cell depletion was not necessarily accompanied by mucosal flattening, as, for example, in mucoviscidosis. Therefore it would seem that the most likely reason for the Paneth cell depletion was 
TABLE V

FREQUENCY OF PANETH CELL OCCURRENCE IN DISEASE OF THE COLON AND RECTUM

Percentage of Specimens with Paneth Cells

\begin{tabular}{|c|c|c|c|c|c|}
\hline \multicolumn{2}{|c|}{$\begin{array}{l}\text { Group } 1 \\
\text { (Between } 0 \text { and } 20 \% \text { ) }\end{array}$} & \multicolumn{2}{|l|}{$\begin{array}{l}\text { Group } 2 \\
\text { (Between } 20 \text { and } 40 \% \text { ) }\end{array}$} & \multicolumn{2}{|c|}{$\begin{array}{l}\text { Group } 3 \\
\text { (Between } 70 \text { and } 80 \% \text { ) }\end{array}$} \\
\hline Disease & Frequency & Disease & Frequency & Disease & Frequency \\
\hline Diverticulosis & 2 of $35(5 \%)$ & $\begin{array}{l}\text { Carcinoma of colon and } \\
\text { rectum }\end{array}$ & 26 of $65(40 \%)$ & Ulcerative colitis & 41 of $44(93 \%)$ \\
\hline Metaplastic polyps & 0 of $16(0 \%)$ & $\begin{array}{l}\text { Adenoma of colon and } \\
\text { rectum }\end{array}$ & 10 of $38(26 \%)$ & Crohn's disease & 14 of $22(64 \%)$ \\
\hline $\begin{array}{l}\text { Peutz Jegher's } \\
\text { polyps }\end{array}$ & 0 of $1(0 \%)$ & $\begin{array}{l}\text { Nonspecific rectal } \\
\text { inflammation }\end{array}$ & 6 of $26(23 \%)$ & Diverticulitis & 12 of $19(63 \%)$ \\
\hline Simple polyps & 0 of $3(0 \%)$ & $\begin{array}{l}\text { Juvenile polyps of colon } \\
\text { and rectum }\end{array}$ & 1 of $4(25 \%)$ & & \\
\hline $\begin{array}{l}\text { Melanosis coli } \\
\text { Hirshsprung's } \\
\text { disease } \\
\text { Mucoviscidosis }\end{array}$ & $\begin{array}{l}0 \text { of } 3(0 \%) \\
0 \text { of } 1(0 \%) \\
0 \text { of } 3(0 \%)\end{array}$ & & & & \\
\hline
\end{tabular}

that it formed part of the general mucosal reaction to injury. In summary, in the small intestine the factors involved in Paneth cell reduction appeared to be an intrinsic abnormality of the Paneth cells as in mucoviscidosis, direct damage as in inflammation, and as part of a general mucosal reaction to injury.

The diseases of the large intestine could be divided into three groups according to the frequency with which the Paneth cells were found (Table V). In group 1, which contained the functional and developmental disorders, Paneth cells were scanty or absent. Those present were probably part of the normal distribution in the colon and unrelated to the intestinal abnormality. Although the juvenile polyps fell into group 2 , they should probably have been included in this group because only one of the four specimens available for examination contained Paneth cells and these appeared to be due to a severe concomitant inflammation. In groups 2 and 3 the number of Paneth cells was increased above normal and the inflammatory conditions were more potent in stimulating Paneth cell production than neoplasms.

The above figures do not altogether reflect the true position because they failed to take into consideration the site of the lesion. This was important in determining the likelihood of finding Paneth cells as these cells were found more frequently in the proximal half than in the distal half of the colon in all diseases, a fact probably related to the normal distribution of the Paneth cell in the colon where Paneth cells are rarely found beyond the splenic flexure. Taking the site of the lesion into consideration, it was found that carcinoma of the proximal half of the colon was accompanied by the Paneth cell nearly as frequently as in ulcerative colitis and Crohn's disease. However, the number ot Paneth cells per specimen was much greater in the inflammations. The relative frequency of these cells in diseases of the distal half of the colon remained unchanged.

The explanation for the presence of Paneth cells in increased numbers in inflammation and neoplasms is not clear. In inflammation repair and regeneration seem to be the most potent stimuli, as seen in chronic active ulcerative colitis (also noted by Watson and Roy, 1960) and in diverticulitis. Acute inflammation or the factors causing it can also produce Paneth cell proliferation, as this increase was found in acute ulcerative colitis in the unaffected areas of the colon.

The incidence and significance of Paneth cells in tumours of the large intestine was discussed by Gibbs (1967), who concluded that Paneth cells occurred either as a result of sequestration or were taking part in the neoplastic process. The results of this investigation confirmed these findings except that neoplastic proliferation of Paneth cells occurred only in one case. However, another factor in Paneth cell proliferation appeared to be the tumour itself or something causing the tumour since Paneth cells were found in increased numbers in the areas adjacent to the neoplasm whether or not these areas showed inflammation. When inflammation occurs it may contribute to proliferation of Paneth cells. It appeared to be responsible for the Paneth cells found in the one juvenile polyp since none was found in the other hamartomas examined. These findings were not borne out by Gibbs (1967) who found Paneth cells in juvenile polyposis and PeutzJeghers polyps. However, the degree of inflammation present in these polyps was not discussed.

SIGNIFICANCE OF CHANGeS IN PANETH CELl POPULATION IN DISEASE In diseases of the small intestine alteration in the number of Paneth cells did not seem to have any effect on the behaviour of the underlying lesion. 
The large intestine reacted to inflammation and tumours by producing an increased number of Paneth cells. Black and Ogle (1948) suggested that Paneth cells secreted a protective factor which inhibited the spread of tumours, because of the fact that carcinomas were so uncommon in the small intestine where Paneth cells occurred in large numbers and so common in the colon where Paneth cells were sparse. However, there is little evidence in favour of this theory because in tumours of the large intestine there are too few Paneth cells adjacent to carcinomas to be of practical significance, and the extent of the tumour spread is unrelated to the number and site of Paneth cells.

Large numbers of Paneth cells, as in ulcerative colitis, may be of some significance. If, as some believe, the Paneth cell produces a proteolytic peptidase, then an excessive number might cause mucosal damage by autodigestion, provided that the peptidase were secreted in sufficient concentration and in the correct milieu. This may explain the differences in clinical behaviour between ulcerative colitis in which very many Paneth cells are found, and other inflammations in which there are far fewer Paneth cells. Once a sufficient number of Paneth cells are produced a self-perpetuating state may develop, in which Paneth cells cause tissue destruction and the reparative process gives rise to new Paneth cells. The reason for the chronicity of ulcerative colitis, and why the causative factor of the disease has never been found, is presumably because by the time the patient is investigated, it has long since ceased to act.

ORIGIN OF THE PANETH CELLS IN THE DISEASED COLON The increased number of Paneth cells in the large bowel could either come from cells migrating from the small intestine or from cells developing locally. The first possibility is unlikely, because cells migrating along the mucosa should be seen on the surface epithelium and they have not been found there. Also there was no evidence of migration of Paneth cells from small bowel to large bowel in specimens in which the ileum was anastomosed to the rectum.

Increased numbers of Paneth cells could develop locally either by the multiplication of Paneth cells normally resident in the colon or by the stimulation of Paneth stem cells. If the former occurs one would perhaps see some Paneth cells in the mitotic phase and an increased number in the crypts of origin. Mitotic figures were not seen in this material, and in carcinoma and diverticulitis Paneth cells were usually found singly in the crypts. Since the Paneth cell is a distinctive cell and has never been shown to develop from the transformation of the other glandular cells of the mucosa, it is most likely to originate in the normal and diseased colon from stem cells in situ.

I am indebted to Dr Ian Dawson for his constant advice and encouragement. I should also like to thank Mrs $\mathrm{H}$. Frances for technical assistance.

I gratefully acknowledge a grant towards expenses from the Governors' discretionary fund of Westminster Hospital.

\section{REFERENCES}

Black, C. E., and Ogle, R. S. (1948). Influence of local acidification of tissue bordering cancerous growths. Arch. Path., 46, 107-118. Creamer, B., and Pink, I. J. (1967). Paneth-cell deficiency. Lancet, 1, 304-306.

Gibbs, N. M. (1967). Incidence and significance of argentaffin and Paneth cells in some tumours of the large intestine. J. clin. Path., 20, 826-831.

Hamperl, H. (1928). Úber erworbene Heterotopien ortsfremden Epithels in Magen-Darmtrakt. Beitr. path. Anat., 80, 307-335.

Helly, K. (1905). Acidophil gekörnte Becherzellen bei Torpedo marmorata. Arch. mikr. Anat., 66, 434-439.

Hertzog, A. J. (1937). The Paneth cell. Amer. J. Path., 13, 351-360.

Kerr, A. B., and Lendrum, A. C. (1936). A chloride-secreting papilloma in the gall-bladder: containing Paneth cells and enterochromaffine cells and associated with massive chloride loss; with a critical review of papilloma of the gall-bladder. A tumour of heterotopic intestinal epithelium. Brit. J. Surg., 23, 615-639.

Laurén, P. (1961). The cell structure and secretion in intestinal cancer. Acta path. microbiol. scand., suppl. 152

Lendrum, A. C. (1948). The surgical significance of some so-called simple tumours. Ann. roy. Coll. Surg. Engl., 3, 32-43.

Lewin, $K$. (1969). The Paneth cell in health and disease. Ibid., 44, 23-37.

Morson, B. C. (1955). Gastric polyps composed of intestinal epithelium. Brit. J. Cancer, 9, 550-557.

- (1959). Histopathology of ine small intestine. Proc. roy. Soc. Med., 52, 6-10.

Paneth, J. (1888). Ueber die secernirenden Zellen des DünndarmEpithels. Arch. mikr. Anat., 31, 113-191.

Paterson, J. C., and Watson, S. H. (1961). Paneth cell metaplasia in ulcerative colitis. Amer. J. Path., 38, 243-249.

Patzelt, V. (1936). Die oxyphilen Panethschen Körnchenzellen. In Der Darm: Handbuch der Mikroskopisher Anatomie des Menschen, edited by W. V. Möollendorff. Vol. 5, part 3, pp. 120-137. Springer, Berlin.

Schmidt, J. E. (1905). Beiträge zur normalen und pathologischen Histologie einiger Zellarten der Schleimhaut des menschlichen Darmkanales. Arch. mikr. Anat., 66, 12-40.

Schwalbe, G. (1872). Beiträge zur Kenntiss der Drüsen in den Darmwandungen ins Besondere der Brünner'schen Drüsen. Ibid., 8, 92-140.

Thorel, C. (1898). Ueber die hyalinen Körper der Magen-und Darmschleimhaut. Virchows Arch. path. Anat., 151, 319-345.

Verity, M. A., Mellinkoff, S. M., Frankland, M., and Greipel, M. (1962). Serotonin content and argentaffin and Paneth cell changes in ulcerative colitis. Gastroenterology, 43, 24-31.

Watson, A. J., and Roy, A. D. (1960). Paneth cells in the large intestine in ulcerative colitis. J. path. Bact., 80, 309-316. 